zeszyt $149,2017,7-14$

doi: 10.4467/20833113PG.17.007.6923

Instytut Geografii i Gospodarki Przestrzennej UJ

Wydawnictwo Uniwersytetu Jagiellońskiego

\title{
PRZYSZEE ZMIANY WYBRANYCH WSKAŹNIKÓW KLIMATYCZNYGH DLA POLSKI NA PODSTAWIE WYNIKÓW DYNAMICZNEGO DOWNSCALINGU
}

\author{
Barbara Brzóska, Adam Jaczereski
}

\section{Future changes of selected climate indices in Poland based on the results of dynamical downscaling}

Abstract: The paper shows the expected changes in selected climatic indices on the basis of the results of dynamic downscaling for the 2041-2070 period with regard to the 1971-2000 period in the Polish territory. Results of the EURO CORDEX simulations with a resolution of $50 \mathrm{~km}$ and $12.5 \mathrm{~km}$ and regional models HIRHAM5, RACMO22E and the RCA4 driven by EC EARTH global climate model and RCP4.5 and RCP8.5 scenarios have been used. The maps showing absolute differences in the following climatic indices: number of frost days, ice days, summer days, wet days and days with precipitation exceeding 10 and $20 \mathrm{~mm}$, between the values obtained in the scenarios and the values obtained for the reference period have been analysed. All the model results show an increase in the global temperature resulting in a decrease in the number of frost and ice days and an increase in the number of summer days. The models also show an increase in the frequency of extreme precipitation. Despite general similarities between the results of the simulations, some differences are evident, mainly due to model-specific setup.

Keywords: climate change, RCP, climate model, temperature, precipitation, climatic indices

Zarys treści: W pracy przedstawiono spodziewane zmiany wybranych wskaźników klimatycznych w Polsce na podstawie wyników dynamicznego downscalingu dla okresu 2041-2070 w odniesieniu do okresu 1971-2000. Wykorzystano wyniki symulacji projektu EUROCORDEX modelami regionalnymi HIRHAM5, RACMO22E i RCA4 o rozdzielczości $50 \mathrm{~km}$ i 12,5 km 
z warunkami brzegowymi i początkowymi z globalnego modelu klimatu ECEARTH oraz scenariuszy RCP4.5 i RCP8.5. Analizie poddano mapy bezwzględnych różnic wskaźników klimatycznych: liczby dni przymrozkowych, mroźnych, gorących, dni z opadem oraz dni z sumą opadu powyżej 10 i $20 \mathrm{~mm}$, między wartościami uzyskanymi w scenariuszu a wartościami uzyskanymi dla symulacji historycznej. Zmiany wskaźników termicznych pokazują wzrost globalnej temperatury, skutkujący spadkiem liczby dni przymrozkowych i mroźnych oraz wzrostem liczby dni gorących. Obserwowany jest również wzrost częstości występowania opadów maksymalnych. Pomimo podobnego ogólnego charakteru zmian w wynikach poszczególnych modeli różnią się one zauważalnie między sobą, na co w dużej mierze mają wpływ szczegóły ich konfiguracji.

Stowa kluczowe: zmiana klimatu, RCP, model klimatu, temperatura, opad, wskaźniki klimatyczne

\section{Wprowadzenie}

Pomimo znacznych osiągnięć, jakich dokonano w ostatnich latach w aspekcie oceny wpływu zmian klimatu na różne dziedziny życia społecznego i gospodarczego w Polsce (np. Wibig, Jakusik 2012), nadal, w wielu dziedzinach, mają one poziom podstawowy. Większość badań skupia się na analizie długookresowego trendu temperatury i wielkości opadu, co jest niewystarczające do oceny skutków zmian klimatu dla poszczególnych sektorów gospodarki oraz określenia rodzaju i zakresu działań adaptacyjnych. Również większość badań preferuje dłuższy horyzont czasowy projekcji klimatu (koniec XXI w.), co dla rozważanych gałęzi gospodarki jest mało przydatne ze względu na ich znacznie większą elastyczność i możliwość dostosowania się. Nie bez znaczenia jest również uchwycenie zmian sezonowych zarówno w skali lokalnej i regionalnej (Jaczewski i in. 2014). Regionalne modele klimatyczne są odpowiednim narzędziem do tego typu badań (Winkler i in. 2011), a obecnie dostępne wyniki ich symulacji są nieocenionym źródłem informacji na ten temat. W niniejszym opracowaniu przeprowadzono analizę wyników symulacji EUROCORDEX (Jacob i in. 2014) i przedstawiono zmiany wybranych wskaźników klimatycznych w latach 2041-2070 w odniesieniu do wielolecia1971-2000.

\section{Dane i metodyka}

W ramach pracy przeprowadzono analizę wyników symulacji projektu EUROCORDEX (Coordinated Downscaling Experiment European Domain) regionalnymi dynamicznymi modelami dla dwóch rozdzielczości: $0,44^{\circ} \times 0,4^{\circ}$ (EUR44, rozdzielczość pozioma ok. $50 \mathrm{~km}$ ) i $0,11^{\circ} \times 0,11^{\circ}$ (EUR11, ok. 12,5 km). Wykorzystano wyniki symulacji dla trzech modeli regionalnych: HIRHAM5, RACMO22E i RCA4. 
Modele te cechują się odmiennymi parametryzacjami procesów fizycznych, były natomiast uruchomione na tej samej domenie przestrzennej, obejmującej kontynent europejski i korzystały z warunków brzegowych i początkowych z tego samego modelu globalnego (EC-EARTH). Szczegóły konfiguracji symulacji zawarte są w pracy Jacoba i in. (2014).

Analizie poddano zmiany wybranych wskaźników klimatycznych (Klein Tank i in. 2009) w latach 2041-2070 w odniesieniu do wielolecia 1971-2000, dla scenariuszy RCP4.5 (Thomson i in. 2011) i RCP8.5 (Riahi i in. 2011):

- liczba dni z $\mathrm{T}_{\min }<0^{\circ} \mathrm{C}$;

- liczba dni z $\mathrm{T}_{\max }<0^{\circ} \mathrm{C}$;

- liczba dni z $\mathrm{T}_{\max }>25^{\circ} \mathrm{C}$;

- liczba dni z opadem;

- liczba dni z dobową wielkością opadu powyżej $10 \mathrm{~mm}$ i $20 \mathrm{~mm}$.

RCP (Representative Concentration Pathways) to zestaw projekcji tylko składników wymuszania radiacyjnego, które mają służyć jako dane wejściowe do modelowania klimatu i chemii atmosfery (Moss i in. 2010). RCP są nazwane zgodnie z ich poziomem wymuszania radiacyjnego w 2100 r. Wymuszanie radiacyjne, czyli zmiana bilansu promieniowania $\mathrm{w}$ atmosferze związana $\mathrm{z}$ zaburzeniem $\mathrm{w}$ systemie klimatycznym (wyrażone $\mathrm{wWm}^{-2}$ ), szacowane jest na podstawie wymuszania przez gazy cieplarniane i inne cząstki wymuszające - ale nie obejmuje bezpośredniego wpływu pokrycia terenu (np. albedo gruntu) czy pyłu mineralnego. RCP zostały opracowane na potrzeby Piątego Raportu Międzyrządowego Panelu ds. Zmian Klimatu (IPCG 2013).

Należy mieć na uwadze, że wyniki symulacji numerycznych różnią się od obserwacji, dlatego niezbędne jest ich porównanie. Ocenę jakości wyników symulacji przeprowadzonych w ramach projektu EURO-CORDEX zawiera praca Kotlarskiego i in. (2014). Zgodnie z wynikami tej pracy średnioroczne różnice temperatury pomiędzy modelami HIRHAM5, RACMO22E i RCA4 oraz pomiarami w naszej części Europy zawierały się w zakresie od $-1,5^{\circ} \mathrm{C}$ do $+0,5^{\circ} \mathrm{C}$, przy czym tylko dla RCA4 (EUR-11) różnica była większa od zera. Podobną zależność dostrzeżono jesienią i zimą. Wiosną natomiast temperaturę przeszacowuje model HIRHAM5 (EUR-11), a latem RCA4 (EUR-44) i HIRHAM5 (EUR-11). W przypadku średniorocznej sumy opadów różnica jest większa od zera i jedynie w przypadku modelu RACMO22E jest mniejsza od akceptowalnej przez autorów różnicy (20\%) wynikającej z niedoszacowywania wartości mierzonych sum opadów przez deszczomierze. Również wiosną, latem i jesienią tylko dla tego modelu różnice nie przekraczają akceptowalnej wartości. Zimą obserwujemy największe przeszacowanie wielkości opadu, przekraczające 40\%, największe dla HIRHAM5 (EUR-44).

Podstawowym celem opracowania wyników było odnalezienie różnic w wynikach regionalnych modeli klimatycznych opartych na tym samym globalnym modelu kli- 
matycznym. Dlatego też policzono różnicę wybranych wskaźników klimatycznych pomiędzy wartościami uzyskanymi dla scenariusza a wartościami uzyskanymi dla symulacji historycznej. Wynikiem był zestaw 11 map (2 rozdzielczości $\times 2$ scenariusze $\times 3$ modele, dla modelu RACMO22E na moment analizy nie była dostępna symulacja RCP4.5 EUR11).

\section{Wyniki}

Pierwszym analizowanym wskaźnikiem była zmiana liczby dni przymrozkowych, czyli dni z temperaturą minimalną poniżej $0^{\circ} \mathrm{C}$ (ryc. 1). Wyniki wszystkich analizowanych modeli przewidują spadek liczby takich dni, dla obu badanych ścieżek emisji, przy czym spadek ten jest większy dla RCP8.5 niż RCP4.5 w ramach tego samego modelu regionalnego (różnice wynoszą średnio dla całej Polski 12-15 dni/rok). Podobnie można zauważyć dla wszystkich modeli, że dla tego samego modelu regionalnego i tej samej ścieżki emisji, modele o mniejszej rozdzielczości przewidują spadki mniejsze o 3-4 dni/rok. Najmniejszy spadek liczby dni przymrozkowych przewiduje model RACMO22E (EUR-44) dla RCP4.5 (średnio dla całego kraju spadek o 23 dni/rok, najmniejszy w rejonie nadmorskim - o 15 dni/rok, największy dla Polski północno-wschodniej - o 28 dni/rok). Największy spadek - model RCA4(EUR-11) dla RCP8.5 (średnio dla całego kraju spadek o 48 dni/rok, dochodzący w Sudetach do spadku o 55 dni/rok). Porównując wyniki symulacji dla tej samej ścieżki emisji i tej samej rozdzielczości przestrzennej, w każdym przypadku najmniejsze zmiany liczby dni z Tmin $<0^{\circ} \mathrm{C}$ przewiduje model RACMO22E, największe - RCA4.

Podobne wyniki uzyskano dla zmiany liczby dni mroźnych, czyli dni z temperaturą maksymalną poniżej $0^{\circ} \mathrm{C}$ (ryc. 2). Dla wszystkich modeli i obu RCP obserwujemy spadek liczby takich dni, większy dla RCP8.5 niż dla RCP4.5 (średnio dla całej Polski o 4-5 dni/rok) oraz większy dla większej (EUR11) rozdzielczości modelu (średnio dla całej Polski o 3-4 dni/rok). Najmniejszy spadek liczby dni mroźnych przewiduje ponownie model RACMO22E dla RCP4.5 przy mniejszej (EUR44) rozdzielczości przestrzennej (średnio dla całego kraju spadek o 7 dni/rok, najmniejszy w Polsce centralnej i zachodniej - o 3 dni/rok, największy w Karpatach - o 13 dni/rok). Największy natomiast spadek - model HIRHAM5 dla RCP8.5 przy większej rozdzielczości przestrzennej (średnio dla całego kraju spadek o 29 dni/rok, dochodzący dla Polski północno-wschodniej do spadku o 37 dni/rok). Porównując wyniki symulacji dla tej samej ścieżki emisji i tej samej rozdzielczości przestrzennej, ponownie w każdym przypadku najmniejsze zmiany liczby dni $\mathrm{z}_{\text {max }}<0^{\circ} \mathrm{C}$ przewiduje model RACMO22E, największe natomiast tym razem HIRHAM5.

Zmiana liczby dni gorących, czyli dni z temperaturą maksymalną powyżej $25^{\circ} \mathrm{C}$ (ryc. 3) jest większa od zera dla wszystkich modeli i obu ścieżek emisji. Dla wszyst- 

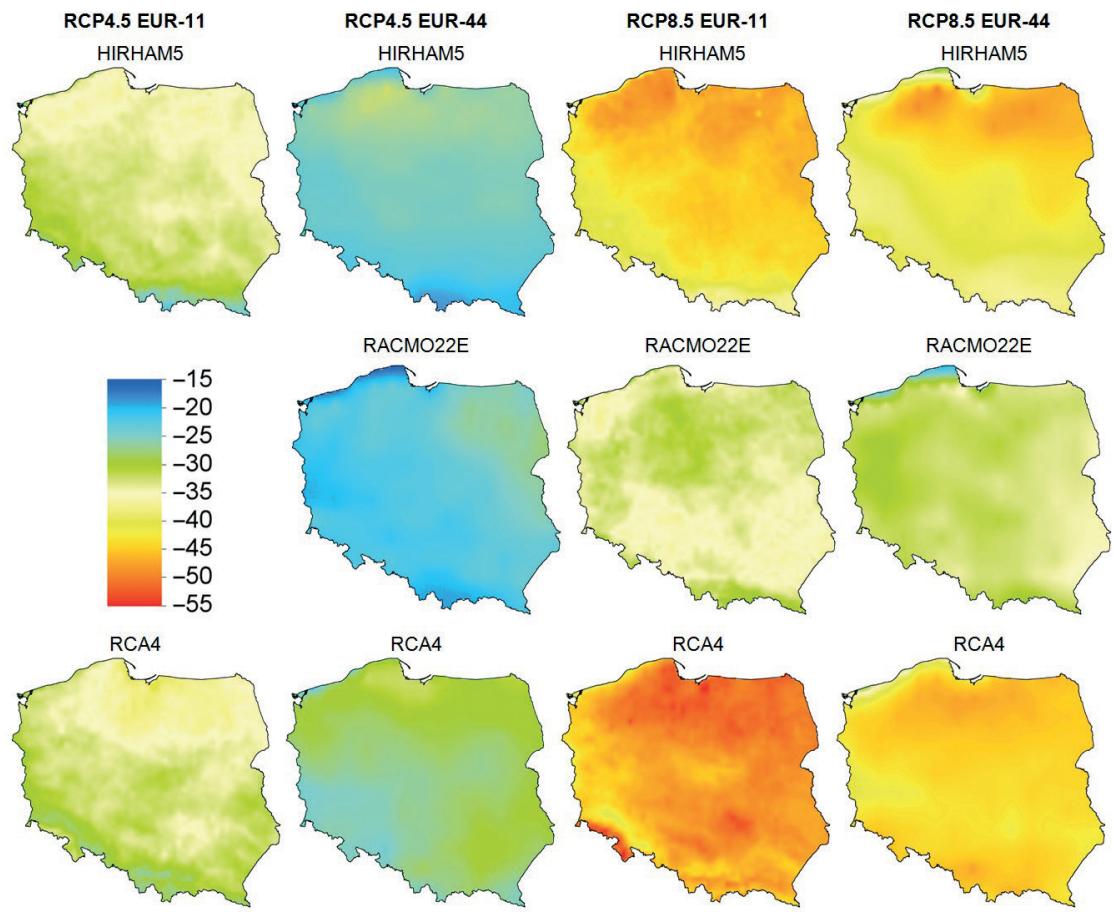

Ryc. 1. Średnia roczna zmiana liczby dni $z \mathrm{~T}_{\min }<0^{\circ} \mathrm{C}$ (dni przymrozkowe) między okresem scenariuszowym a referencyjnym dla RCP4.5 (dwie pierwsze kolumny) i RCP8.5 (dwie ostatnie kolumny), rozdzielczości $0,11^{\circ} \times 0,11^{\circ}$ (pierwsza i trzecia kolumna) i $0,44^{\circ} \times 0,44^{\circ}$ (druga i czwarta kolumna) oraz 3 regionalnych modeli klimatu (pierwszy wiersz - HIRHAM5, drugi wiersz - RACMO22E, trzeci wiersz - RCA4)

Fig. 1. Average differences in the number of days with $\mathrm{T}_{\min }<0^{\circ} \mathrm{C}$ (frost days) between scenario simulations and the reference one for RCP4.5 (first two columns) and RCP8.5 (last two columns), $0,11^{\circ} \times 0,11^{\circ}$ (first and third column) and $0,44^{\circ} \times 0,44^{\circ}$ (second and fourth column) resolutions and three regional climate models (first row - HIRHAM5, second row - RACMO22E, third row - RCA4) 

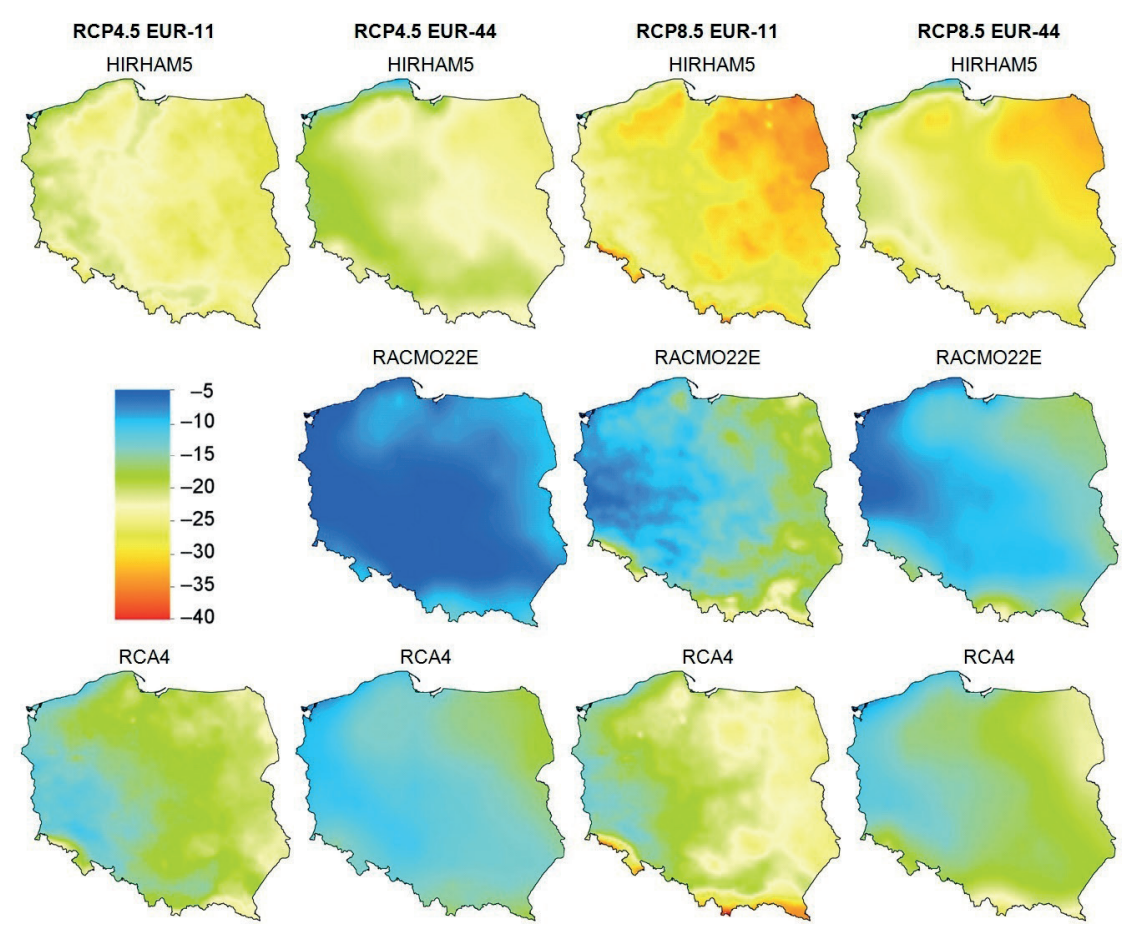

Ryc. 2. Średnia roczna zmiana liczby dni $\mathrm{z} \mathrm{T}_{\max }<0^{\circ} \mathrm{C}$ (dni mroźne) (opis układu rysunków znajduje się w opisie ryc. 1)

Fig. 2. Average differences in the number of days with $\mathrm{T}_{\max }<0^{\circ} \mathrm{C}$ (ice days). For figure's composition description see label of Fig. 1 

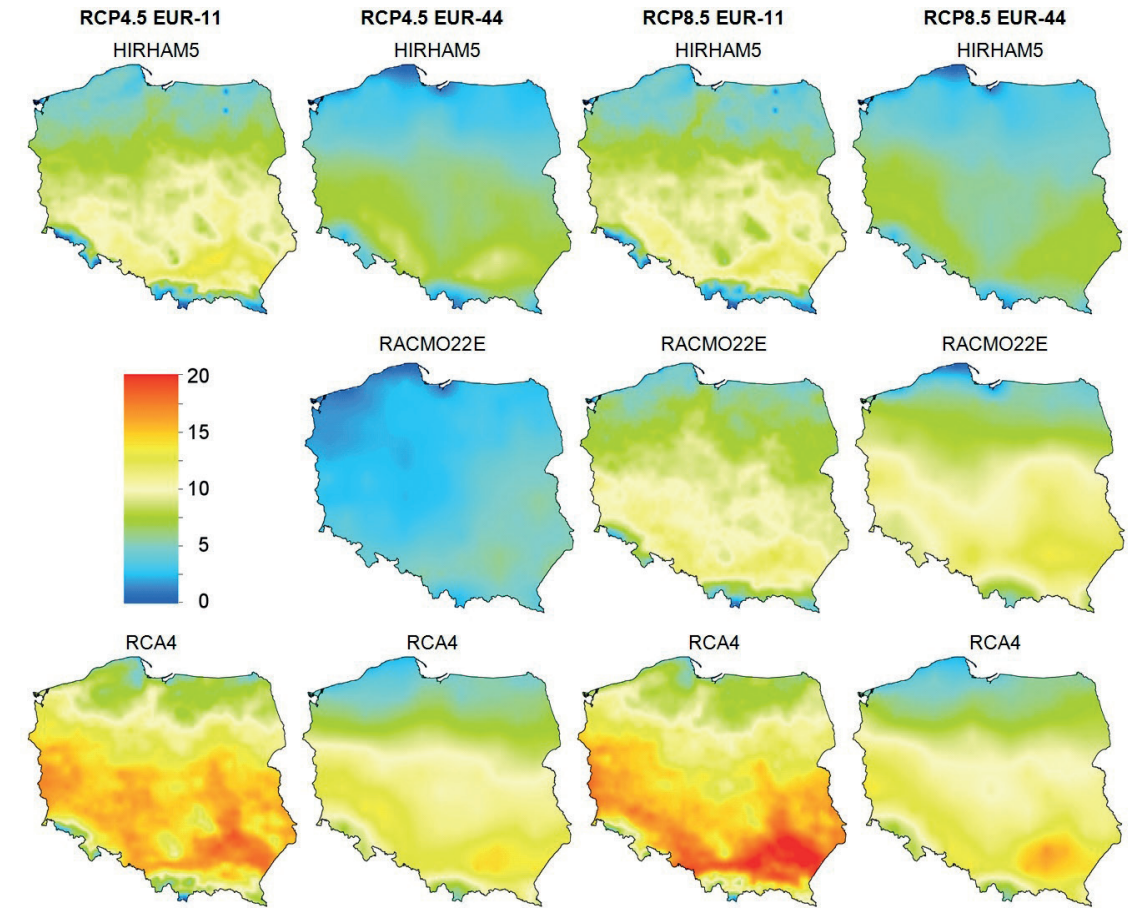

Ryc. 3. Średnia roczna zmiana liczby dni z $\mathrm{T}_{\max }>25^{\circ} \mathrm{C}$ (dni gorące) (opis układu rysunków znajduje się w opisie ryc. 1)

Fig. 3. Average differences in the number of days with $\mathrm{T}_{\text {max }}>25^{\circ} \mathrm{C}$ (summer days). For figure's composition description see label of Fig. 1 

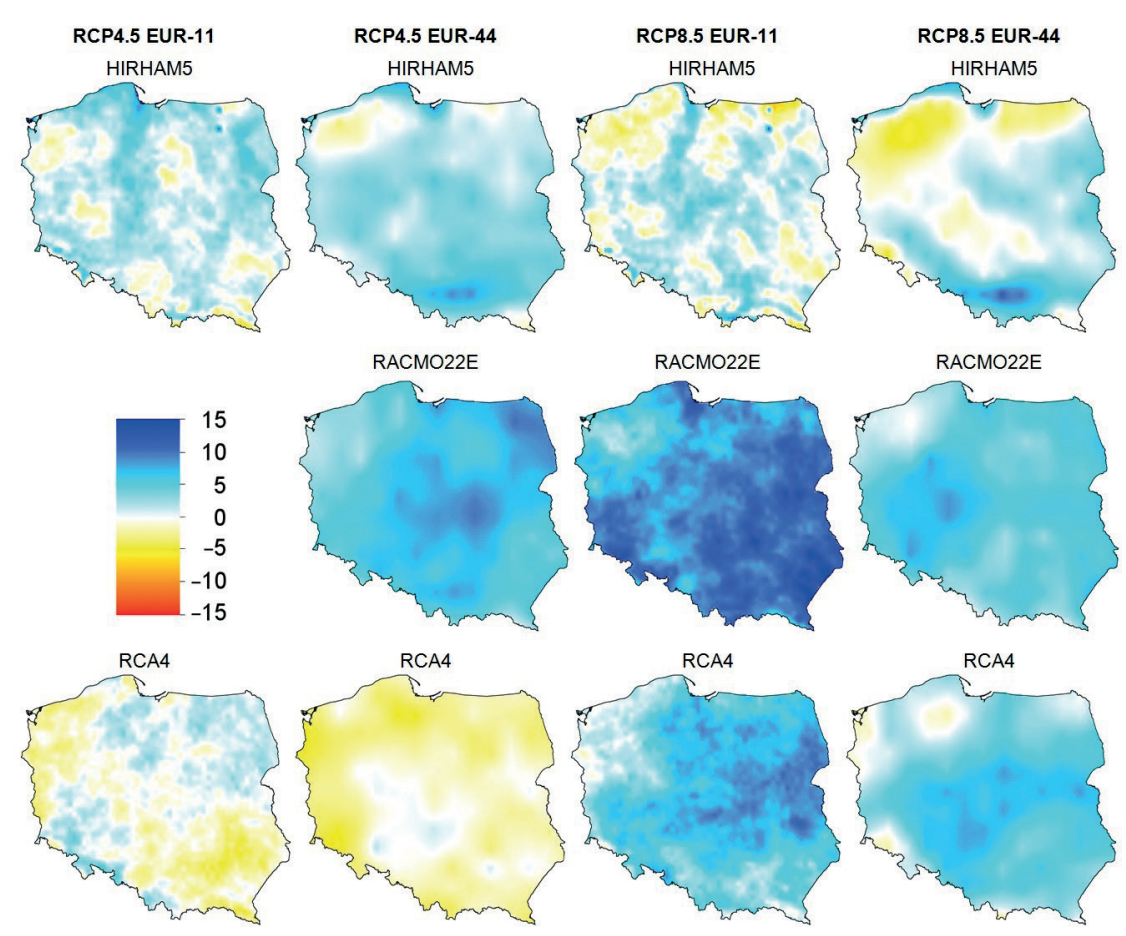

Ryc. 4. Średnia roczna zmiana liczby dni z opadem (opis układu rysunków znajduje się w opisie ryc. 1)

Fig. 4. Average differences in the number of wet days. For figures's composition description see label of Fig. 1 

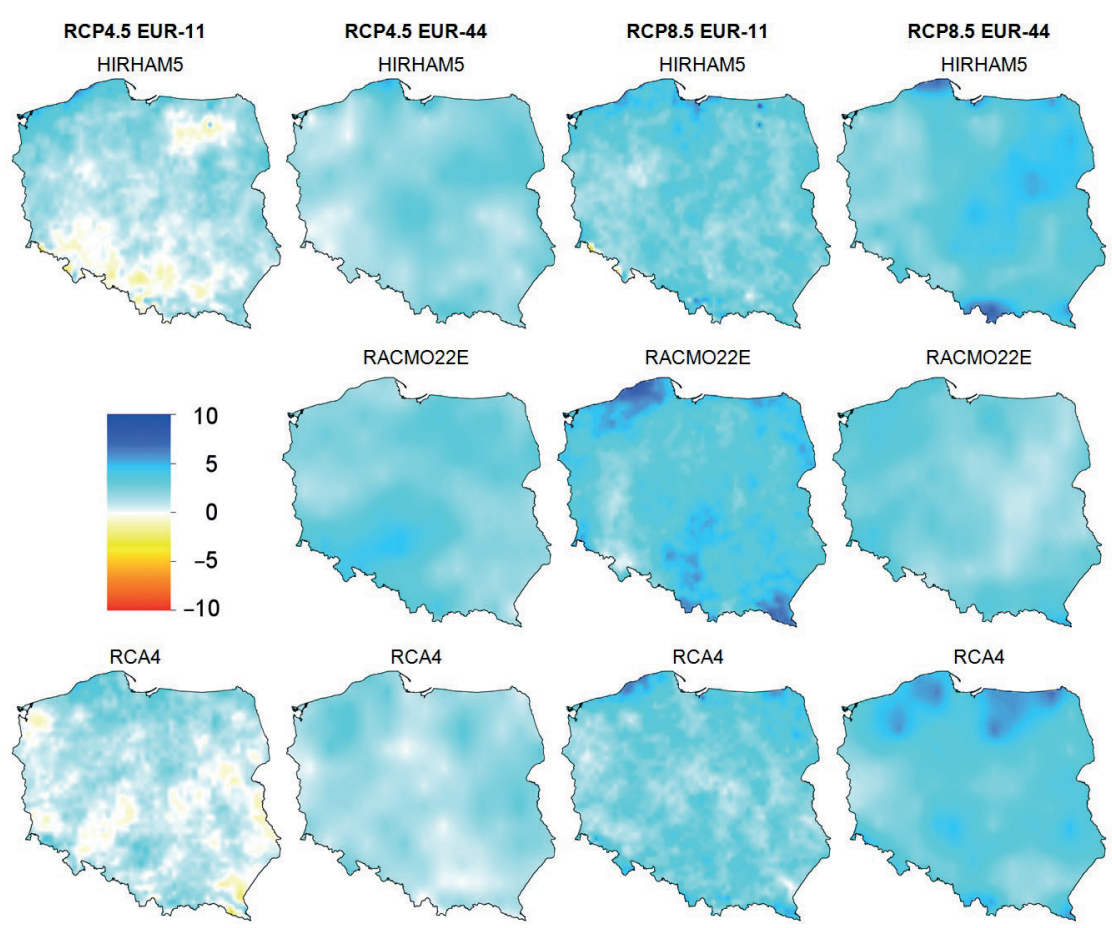

Ryc. 5. Średnia roczna zmiana liczby dni z sumą opadu powyżej $10 \mathrm{~mm}$ (opis układu rysunków znajduje się w opisie ryc. 1)

Fig. 5. Average differences in the number of days with precipitation above $10 \mathrm{~mm}$. For figure's composition description see label of Fig. 1 

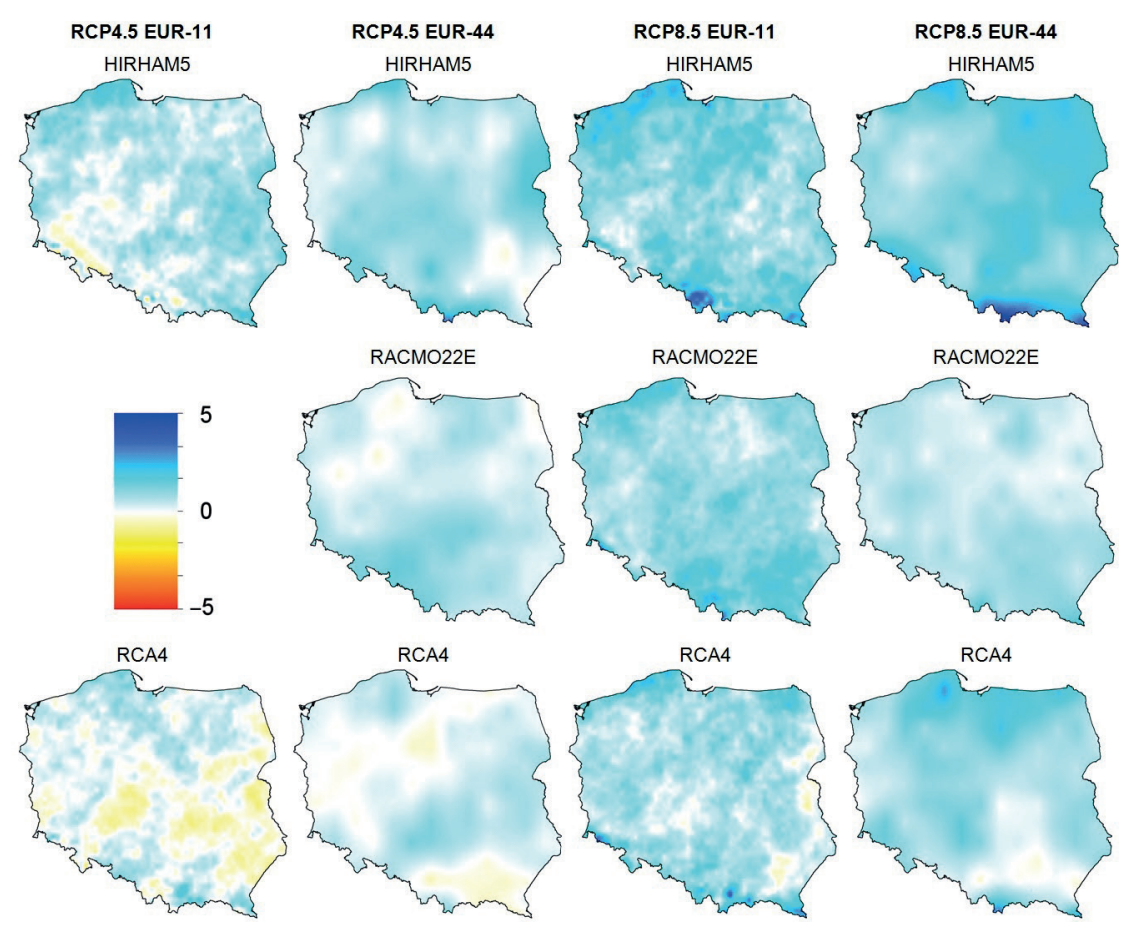

Ryc. 6. Średnia roczna zmiana liczby dni sumą opadu powyżej $20 \mathrm{~mm}$ (opis układu rysunków znajduje się w opisie ryc. 1)

Fig. 6. Average differences in the number of days with precipitation above $20 \mathrm{~mm}$. For figure's composition description see label of Fig. 1 
kich modeli dla obu ścieżek emisji i obu rozdzielczości obserwujemy wzrost liczby tych dni. Najmniejszy wzrost przewiduje RACMO22E (EUR-44) dla RCP4.5 (średni wzrost liczby tych dni dla obszaru Polski wynosi 4 dni/rok, a w obszarze nadmorskim wzrost ten jest niezauważalny), największy natomiast model RCA4 (EUR-11) dla RCP8.5, który przewiduje dla całego kraju średni wzrost liczby dni gorących o 13 dni/ rok, a dla Kotliny Sandomierskiej, Wyżyny Kieleckiej i Wyżyny Lubelskiej dochodzący nawet do $21 \mathrm{dni} /$ rok. Z analizy zmiany liczby dni gorących z punktu widzenia różnych ścieżek emisji lub różnych rozdzielczości przestrzennych wynika, że modele zachowują się podobnie jak w przypadku zmian liczby dni przymrozkowych i mroźnych, choć różnice są tu mniejsze. Symulacje dla RCP8.5 przewidują średnio na obszarze Polski wzrost liczby dni $\mathrm{z}_{\max }<25^{\circ} \mathrm{C}$ większy średnio o 3-5 dni/rok niż symulacje oparte na RCP4.5, natomiast symulacje o rozdzielczości 12,5 km przewidują średnio wzrost większy o 23 dni/rok niż symulacje w mniejszej rozdzielczości. Przyglądając się różnicom pomiędzy różnymi modelami regionalnymi dla tej samej ścieżki emisji i rozdzielczości przestrzennej, widzimy, że najmniejsze wzrosty przewidywane są przez model RACMO22E, największe zaś przez model RCA4.

Na ryc. 4 przedstawiona jest średnia roczna zmiana liczby dni z opadem. Projekcje modeli nie są już tak jednoznaczne jak w przypadku zmian wskaźników termicznych. Model RACMO22E przewiduje wzrost liczby dni z opadem. Pozostałe dwa modele przewidują zarówno wzrost liczby dni z opadem, jak i ich spadek. Największy wzrost liczby dni z opadem przewiduje RACMO22E (EUR-11) dla RCP8.5. Średnio na obszarze całego kraju wzrost ten ma wynieść 9 dni/rok, a w skrajnych przypadkach ma to być nawet 16 dni/rok (dla Polski południowo-wschodniej). Przeciwnie - model RCA4 (EUR-44) dla RCP4.5, który przewiduje średnio dla całego kraju spadek liczby dni z opadem ( 2 dni/rok), a dla Polski zachodniej nawet 6 dni/rok. Nie występują obszary, na których zaobserwować można dla wszystkich symulacji spadek bądź wzrost opadów, jedynie dla obszaru Polski centralnej wyniki modelowania wskazują na wzrost liczby dni z opadem dla prawie wszystkich symulacji.

Zmiany liczby dni z dobową sumą opadu powyżej $10 \mathrm{~mm}$ i $20 \mathrm{~mm}$ są bardziej jednoznaczne (ryc. 5 i 6). Większość wyników symulacji wskazuje na wzrost liczby dni z takimi opadami. Jedynie HIRHAM5 i RCA4 dla RCP4.5 i rozdzielczości 12,5 km przewidują spadek liczby takich dni dla niewielkich obszarów Polski. Przewidywane spadki wynoszą maksymalnie 4 dni/rok w przypadku sumy opadu przekraczającej $10 \mathrm{~mm}$, oraz $2 \mathrm{dni} /$ rok dla sumy opadu powyżej $20 \mathrm{~mm}$. W każdym przypadku średnio dla całej Polski przewidywany jest wzrost liczby takich dni. Największy wzrost liczby dni z sumą opadu powyżej $10 \mathrm{~mm}$ obserwujemy dla modelu RACMO22E dla RCP8.5 i większej rozdzielczości przestrzennej (średnio dla obszaru całego kraju 4 dni/rok, dochodzący do 8 dni/rok dla Pobrzeża Koszalińskiego i Bieszczad Lesistych). W przypadku zmiany liczby dni z sumą opadu powyżej $20 \mathrm{~mm}$ różnice pomiędzy symulacjami są mało wyraźne. Przewidywany wzrost wynosi 1 dzień/rok 
na większości obszaru kraju, największy - 6 dni/rok w Centralnych Karpatach Zachodnich w wynikach modelu HIRHAM5 (EUR-44) dla RCP8.6.

\section{Podsumowanie}

Wyniki symulacji regionalnymi dynamicznymi modelami klimatu przewidują wzrost liczby dni gorących oraz spadek liczby dni mroźnych i przymrozkowych w Polsce. Tendencje tych zmian są skutkiem obserwowanego globalnego wzrostu temperatury, ale ich wielkość jest różna dla różnych modeli i rozdzielczości. Dla danego modelu i rozdzielczości symulacje RCP8.5 przewidują odpowiednio mniejszy wzrost i spadek od RCP4.5, co jest skutkiem odpowiednio większego globalnego wzrostu temperatury w RCP8.5. Model RACMO22E przewiduje odpowiednio najmniejsze wzrosty i spadki liczby dni gorących oraz mroźnych i przymrozkowych.

W przypadku wskaźników opadowych wyraźnie widoczne są różnice w przewidywaniach zmian liczby dni z opadem. Model RACMO22E przewiduje największy wzrost liczby takich dni. Model RCA4 przewiduje spadek liczby takich dni dla RCP4.5, a wzrost dla RCP8.5. W przypadku liczby dni z opadem maksymalnym widać wyraźnie zależność od rozdzielczości, ale tylko dla RCP4.5. Modele przewidują w pewnych obszarach kraju spadek liczby takich dni dla EUR-11, a wzrost dla EUR-44. Z jednej strony Wiel i in. (2016) zauważyli poprawę jakości modelowania opadów ekstremalnych wraz ze wzrostem rozdzielczości modelu, z drugiej jednak strony należy zdawać sobie sprawę z ograniczenia stosowalności parametryzacji konwekcji w większych rozdzielczościach przestrzennych (Pieri i in. 2015).

Zauważone różnice w przewidywanych zmianach wskaźników termicznych należy przypisać zastosowaniu w modelach różnych parametryzacji promieniowania, powierzchni ziemi i warstwy granicznej. W przypadku opadu istotny wpływ na wyniki ma przyjęty schemat mikrofizyki i konwekcji oraz rozdzielczość symulacji. Choć wyniki symulacji o większej rozdzielczości (EUR-11) pokazują bardziej szczegółowy przestrzenny obraz zmian, to ich praktyczne zastosowanie może być ograniczone ze względu na uśrednianie przestrzenne danych modelowych w procesie opracowywania scenariuszy (Wibig, Jakusik 2012). Dodatkowo na różnice w projekcjach klimatu pomiędzy modelami wpływa brak stacjonarności błędu modelu czy odmiennie symulowana zmienność obecnego i przyszłego klimatu (Wibig, Jędruszkiewicz 2015). 


\section{Literatura}

IPCC, 2013, Stocker T.F., Qin D., Plattner G.-K., Tignor M., Allen S.K., Boschung J., Nauels A., Xia Y., Bex V., Midgley P.M. (red.), Climate change 2013: The physical science basis: Contribution of working group $i$ to the fifth assessment report of the intergovernmental panel on climate change, Cambridge University Press, Cambridge.

Jacob D., Petersen J., Eggert B., Alias A., Christensen O.B., Bouwer L.M., Braun A., Colette A., Déqué M., Georgievski G., Georgopoulou E., Gobiet A., Menut L., Nikulin G., Haensler A., Hempelmann N., Jones C., Keuler K., Kovats S., Kröner N., Kotlarski S., Kriegsmann A., Martin E., van Meijgaard E., Moseley C., Pfeifer S., Preuschmann S., Radermacher C., Radtke K., Rechid D., Rounsevell M., Samuelsson P., Somot S., Soussana J.-F., Teichmann C., Valentini R., Vautard R., Weber B., Yiou P., 2014, EURO-CORDEX: New high-resolution climate change projections for European impact research, Regional Environmental Change, 14 (2), 563-578.

Jaczewski A., Brzóska B., Wibig J., 2015, Comparison of temperature indices for three IPCC SRES scenarios based on RegCM simulations for Poland in 2011-2030 period, MeteorologischeZeitschrift, 24 (1), 99-106.

Klein Tank A.M.G., Zwiers F.W., Zhang X., 2009, Guidelines on Analysis of extremes in a changing climate in support of informed decisions for adaptation, WMO Climate Data and Monitoring, 1500 (72), 56.

Kotlarski S., Keuler K., Christensen O.B., Colette A., Déqué M., Gobiet A., Goergen K., Jacob D., Lüthi D., Meijgaard E. van, Nikulin G., Schär C., Teichmann C., Vautard R., Warrach-Sagi K., Wulfmeyer V., 2014, Regional climate modeling on European scales: A joint standard evaluation of the EURO-CORDEX RGM ensemble, Geoscientific Model Development, 7 (4), 1297-1333.

Moss R.H., Edmonds J.A., Hibbard K.A., Manning M.R., Rose S.K., Vuuren D.P. van, Carter T.R., Emori S., Kainuma M., Kram T., Meehl G.A., Mitchell J.F.B., Nakicenovic N., Riahi K., Smith S.J., Stouffer R.J., Thomson A.M., Weyant J.P., Wilbanks T.J., 2010, The next generation of scenarios for climate change research and assessment, Nature, 463 (7282) 747-756.

Pieri A.B., Hardenberg J. von, Parodi A., Provenzale A., 2015, Sensitivity of precipitation statistics to resolution, microphysics, and convective parameterization: A case study with the high-resolution WRF Climate Model over Europe, Journal of Hydrometeorology, 16 (4), 1857-1872.

Riahi K., Rao S., Krey V., Cho C., Chirkov V., Fischer G., Kindermann G., Nakicenovic N.,Rafaj P., 2011, RCP 8.5 - A scenario of comparatively high greenhouse gas emissions, Climatic Change, 109 (1-2), 33-57.

Thomson A.M., Calvin K.V., Smith S.J., Kyle G.P., Volke A., Patel P., Delgado-Arias S., Bond-Lamberty B., Wise M.A., Clarke L.E., Edmonds J.A., 2011, RCP4.5: A pathway for stabilization of radiative forcing by 2100, Climatic Change, 109 (1-2), 77-94. 
Wibig J., Jakusik E. (red.), 2012, Wptyw zmian klimatu na środowisko, gospodarkę i spoteczeństwo. Zmiany, skutki i sposoby ich ogranicæania, wnioski dla nauki, praktyki inżynierskiej i planowania gospodarczego, Instytut Meteorologii i Gospodarki Wodnej-Państwowy Instytut Badawczy, Warszawa.

Wibig J., Jędruszkiewicz J., 2015, How reliable are selected methods of projections of future thermal conditions? A case from Poland, Quaestiones Geographicae, 34 (3), 151-160.

Wiel K. van der, Kapnick S.B., Vecchi G.A., Cooke W.F., Delworth T.L., Jia L., Murakami H., Underwood S., Zeng F., 2016,The resolution dependence of contiguous U.S. Precipitation extremes in response to $\mathrm{CO}_{2}$ forcing, Journal of Climate, 29 (22), 7991-8012.

Winkler J.A., Guentchev G.S., Perdinan, Tan P.-N., Zhong S., Liszewska M., Abraham Z., Niedźwiedź T., Ustrnul Z., 2011, Climate scenario development and applications for locall regional climate change impact assessments: An overview for the non-climate scientist, Part I: Scenario development using downscaling methods, Geography Compass, 5 (6), 275-300.

Barbara Brzóska

Instytut Meteorologii i Gospodarki Wodnej - Państwowy Instytut Badawczy

ul. Podleśna 61,01-673 Warszawa

bbkk99@wp.pl

Adam Jačewski

Instytut Meteorologii i Gospodarki Wodnej-Państwowy Instytut Badawczy

ul. Podleśna 61,01-673 Warszawa

Adam.Jaczewski@imgw.pl 